\title{
SOCIAL INNOVATION AS A POLICY RESPONSE TO RESTRUCTURE THE WELFARE STATE
}

\author{
Doğa Başar Sariipek \\ associate professor, Kocaeli University \\ Umuttepe Yerleşkesi, 41001, İzmit/KOCAELI, e-mail: sariipek@kocaeli.edu.tr \\ Gökçe Cerev \\ associate professor, Kocaeli University \\ Umuttepe Yerleşkesi, 41001, İzmit/KOCAELİ, e-mail: cerevgokce4@gmail.com \\ Bora Yenihan \\ associate professor, Kocaeli University \\ Umuttepe Yerleşkesi, 41001, İzmit/KOCAELI, e-mail: borayenihan@gmail.com
}

\begin{abstract}
The focus of this paper is the interaction between social innovation and restructuring welfare state. Modern welfare states have been reconfiguring their welfare mixes through social innovation. This includes a productive integration of formal and informal actors with support and leading role of the state. This collaboration becomes significantly important since it means the integration of not only the actors, but also their capabilities and resources in today's world where new social risks and new social challenges have emerged and no actor can overcome these by its own. Therefore, social innovation is a useful tool in the new role sharing within the welfare mix in order to reach higher levels of satisfaction and success in welfare provision. The main point here is that this is not a zero-sum competition; gaining more power of the actors other than the state - the market, civil society organisations and the family - does not necessarily mean that the state lost its leading role and power. This is rather a new type of cooperation among actors and their capabilities as well as their resources in welfare provision. In this sense, social innovation may contribute well to the debates over the financial crisis of the welfare state since it may lead to the more wisely use of existing resources of welfare actors. Thanks to social innovative programs, not only the NGOs, but also market forces as well as citizens are more active to access welfare provisions and social protection in the broadest sense. Thus, social innovative strategies are definitely a solid step taken towards "enabling" or "active" welfare state.
\end{abstract}

Keywords: Social Innovation, Welfare State, Welfare Mix, Welfare State Crisis

\section{Introduction}

There is no state in the world that provides the wellbeing of its citizens by itself. Even though it is called welfare state, this does not mean necessarily that the whole welfare is provided by the state only. Welfare provision, in fact, is a collaborative process including four distinctive actors at the same time - the state/government, the market/private organisations, the family/individuals and community/charity. Each society has its own mixture composing of these actors. The ultimate goal is always 
reaching the highest level of quality of life with the least cost possible. Governments, in this sense, are always in search of the best practice in welfare provision.

Promising higher level of wellbeing, social innovation has stood out recently and been spreading increasingly among welfare states. It is not a fifth actor though; but it definitely has a real potential to integrate all actors in harmony in the production and provision of wellbeing. It also paves the way for debates over "enabling welfare state" or "active welfare state" by employing more responsibility to the actors other than the state and enabling the production of welfare from "bottom-to-top" instead of "top-to-the-bottom", namely the traditional post-war welfare state.

In order to deal with these points, this study includes three parts. In the first part, it starts with a general framework for the discussion. However, instead of giving general definition of social innovation, which is known very well by everyone studying in this field, it develops a tailored discussion relating social innovation directly to the welfare state. The obvious advantages and contributions of social innovation in the attempt to be an "enabling" or "active" welfare state is the main moving point of the first part.

In the following part, the study moves on to the discussion of re-organisation of welfare mix in the context of social innovation. Relying on theoretical analysis of different welfare mixes of social innovation practices, in the final part, the paper includes the welfare failure that today's welfare societies face due to the inconsistency between changing risks and traditional post-war welfare state practices. By doing so, we paid particular attention to develop customised discussion in each part of the study by avoiding general explanations on welfare state. In the conclusion, we give further details about our own inference on the relationship between social innovation and financial crisis of welfare state and discuss whether social innovation can contribute significantly to improve the existing level of wellbeing in modern welfare states.

\section{Search for a More Activated Welfare State via Social Innovation}

Welfare states all over the world have been suffering from a financial crisis for the last couple of years. There are many studies, in this sense, calling this process a transition from "traditional post-war Keynesian welfare state" to "Schumpeterian workfare state" (Jessop, 1991, 1995; Torfing, 1999) or "enabling welfare state" (Gilbert, 2002; Gilbert and Gilbert, 1989) as well as "active welfare state" (OECD, 1990) and welfare to workfare (Mascini et. al., 2011; Gough, 2000). These studies suggest that the idea of decommodification, which was the key point of traditional welfare state practices, has ended and it is being replaced by commodification policies through the attribution of new roles to welfare providing actors other than the state.

This shift in welfare provision has various dimensions including active labour force practices and support for employability, strict encouragement of labour market participation, rebalancing the rights and obligations and an increase in conditionality before enjoying rights. In other words, entitlement to any welfare right has been tied up strictly to be an active citizen.

The main motivation behind this policy is to maintain the existing level of wellbeing and, in fact, to improve it continuously. Broadly speaking, generosity of welfare state, which is a dependent variable, relies heavily on financial capacity of states in the first place. Thus, insisting on post-Keynesian welfare state, which was the product of post-war economic expansion, does not seem proper under today's global economic downturns. In this sense, welfare states seek to enable other welfare providing actors more complementary to the state. This "enabling welfare state" admits that complementary support from private organisations, interpersonal cooperation networks, civil society organisations and partici- 
pation in community and civic life in general are key factors to enjoy the same level of wellbeing and improve it continuously even during times of economic hardships. The state undertakes a rather moderator and organising role along with being still the direct provider in some crucial areas in the scope of rights-based approach. This new role sharing between the state and other actors encourages individuals and communities to be more active in determining and maximizing their own wellbeing on the one hand and leads a decline in public welfare expenditures on the other. Therefore, enabling welfare state discriminates itself clearly from the classical one with "bottom-to-top" service delivery instead of "top-to-bottom".

It is no doubt that this is a clear paradigm shift in welfare state thought. However, how to reach this ultimate goal needs clear answers and social innovation strategies offer a novel way of response for this question by enabling both a fruitful cooperation between different actors and more power to citizens on self-determining their own wellbeing. Another benefit of applying social innovation strategies in welfare delivery is that it may lead taking preventive measures rather than compensating ones, which is obviously the most proper way of welfare administration. Broadly, social innovation programs encourage market forces to undertake social policy initiatives more and establishing stronger cooperation ties with communities in order to overcome social problems, including new social risks (Jenson, 2014: 6).

\section{Social Innovation and Changing Welfare Mix}

All welfare states, without any exception, rely on a combination of four main actors- state, market, family and NGOs. The interdependent relations among these actors is called welfare mix and welfare is produced and allocated between them (Longo et al., 2015: 2; Powell and Barrientos, 2011: 76; Esping-Andersen, 1999). The shares of these actors in the combination define the type of the welfare regime. For instance, while the market is expected to take over a prominent role in a liberal welfare regime, the state has always a leading position in a social democratic regime. In fact, the nature of the combination also define whether there is right-based or charity-based social welfare in a society as well.

While rights-based social protection offers certain advantages to citizens in terms of social protection guarantees, it is not easy to maintain it under today's austerity programs since they diminish the leading role of the state. Therefore, modern welfare states seek ways to reduce the responsibilities of the state and increase the role of other actors. Social innovation, in this sense, seems a proper and useful mechanism to complement the state well in welfare provision. Firmly speaking, by mobilising various for-profit and civil society actors and resources and thereby creating a fruitful synergy in specific social problem fields, such as health, housing, inclusive education, discrimination and labour market activation, social innovation may offer a successful and cost-effective collaboration among actors (Oosterlynck et al., 2019; BEPA, 2011; Kazepov, 2008; 2010; Ascoli and Ranci, 2002).

Social innovation reconstructs the cooperation between the state, private companies/employers, civil society, and even the philanthropists in a way that they can deal with social needs and challenges far better (Jenson, 2015; Hämäläinen and Heiskala, 2007). Every actor has their own instruments to tackle with social needs. Societies that can coordinate these actors and their instruments more successfully enjoy a higher level of social protection. Social innovation is definitely one of the best solutions to establish such a cooperation. Thus, the state has to set the required legal and institutional scene for this and must support social innovation practices financially to enable the sustainability. In this respect, there has been a clear transformation in the welfare provision roles of the state; the state has 
moved to the role of facilitating cooperation between actors instead of being a direct provider. This strategy is one of the most common methods that welfare states have resorted to in solving the financial crisis they have faced recently.

What is noteworthy here is that welfare cooperation among actors is nothing new; (EspingAndersen, 2002; Bode, 2006) there has always been a mixed welfare systems and the state has never been the sole providing actor (Spicker, 2008; Garland, 2014). However, the type and method of application change over time. While the market, for instance, may come to the fore from time to time, the civil society and/or family may gain importance another time. Nevertheless, the state is always the leading actor, which defines not only the shape of welfare provision, but also the roles and responsibilities of formal and informal actors. Since welfare systems are dependent variables depending on socioeconomic risks, they must constantly adapt themselves according to the changing nature of risks. Otherwise, traditional welfare states cannot response properly to, for instance, "new social risks" as they were designed accordingly to old ones (Bonoli, 2005) and they cannot be maintained under the pressures of austerity. This is the main reasoning of the shift from "passive" or "providing" welfare state to "active" or "enabling" welfare state (Morel et al., 2012).

\section{Social Innovation and Civil Society Cooperation}

All welfare actors may take place in social innovation practices. However, civil society organisations are expected to be the natural leading agents in social innovation projects. This may stem from a number of reasons. First, existing austerity measures in welfare states encourage them to empower civil society in social issues in an attempt to share the wellbeing provision responsibility of the state. Second, the very reason of existence of civil society is to address the unsolved social problems in the first place. Besides, civil society organisations are more likely to be neutral to any ideology or politics and therefore, they may gather people, private companies and even local and central authorities from different thoughts under a common goal.

Civil society organisations also represent a good response to standardized and uniform welfare provisions of the state. In other words, the type and intensity of social risks may vary from person to person and tailored interventions may be needed accordingly. This may be much easier for a civil society organisation rather than a central state authority. All these reasons make civil society organisations the dominant resource for innovation in welfare provision on the one hand and a good bridge between provisions and the citizen in many welfare states on the other (Ewert and Evers, 2014; Bode, 2006).

Although transformations in the welfare mix take different forms in different countries, what is certain is that there is a clear decline in the role of the state as the direct provider, but an increase in the role of facilitator. Social innovation practices, in this sense, are good examples of "civil society and welfare state partnership" (Bode, 2006: 354). The degree of this partnership may vary significantly, but in order to talk about a fruitful and effective social innovation practice initiated by a civil society organisation, the state must set the available legal environment and support civil society organisations financially. Otherwise, it would not be easy to claim a satisfactory and sustainable social innovation experience in a society.

Moreover, this partnership must be established out of the politics sphere and must lead a constructive competition among civil society organisations. As seen clearly, the state remains being the dominant and leading actor in welfare provision, but role it undertakes has shifted towards facilitator and coordinator. This is the new style of welfare regime in today's world; due to the restrictions 
stemming from austerity pressures on societies, welfare regimes have started to transform into "bottom-to-top provision systems" thanks particularly to social innovation practices, which made it easier for state to establish partnerships with other welfare providing actors.

\section{Social Innovation Programs as a Remedy for "Welfare Failure"}

Despite the significantly high social protection expenditures in many welfare states for several decades, the desired achievements in development indicators, especially poverty and unemployment, have not been achieved. Even mature welfare societies suffer from massive and permanent unemployment; having a regular job with a stable income alone cannot guarantee to get out of poverty and enjoy a decent life. These facts indicates a definite welfare failure and show us that the welfare state must be constantly updated in conformity with changing socioeconomic and cultural conditions. This means there is no unchanged and timeless social protection policies, which is indefinite to societal transformations but offering full immunity to all socioeconomic risks. In short, it is an unavoidable fact to see welfare failures in communities if there is a definite insist on traditional welfare policies against untraditional social problems and risks.

Considering these facts, welfare societies have long been searching for the best ways to update their welfare policies in accordance with changes in society. The new era requires more cost-effective solutions through close collaboration of all providers, new entitlement rules before enjoying rights, a strengthening focus on the principle of reciprocity, active citizens, active communities and active markets in terms of provision of social welfare. Even though welfare states employ several ways to achieve these activation policies and become "enabling welfare state", social innovation strategies stand out as one of the most promising ways of reaching this goal. Even the European Union has given social innovation strategies a solid place in its policy documents over the last decade. In this sense, the largest public research funding programme of Europe, the "Horizon 2020" was framed in the context of social innovation. (https://ec.europa.eu/programmes/horizon2020/en/home)

Indicating a definite paradigm shift in social protection measures, social innovation promises to overcome welfare failures of welfare societies by relaxing governments in regards of budgetary restraints as well as providing local and flexible, thus more cost-effective solutions to previously unmet social needs (BEPA, 2011: 14). In short, social innovation offers a collaboratively development opportunity to welfare societies. This is a sustainable development attempt, which is "beyond the state" even though the state is still the essential facilitator and enabler, by urging the hidden capacities of communities, markets and civil society organisations (Jenson, 2014, 2015).

\section{Summary}

Attempts to overcome the financial crisis of the welfare state is not new. Modern welfare states have tried various methods for this purpose from time to time. The essence of these attempts is having a decline in the active and direct role of the state, but an increase in the role of other three - the market, community and the family. Among all methods, social innovation seems more promising since it offers a more balanced and more complementary division of labour in welfare mix.

In this more balanced role sharing, the state and its institutions remain crucial actors in the welfare mix in an attempt to pave the way for socially innovative practices. This may seem like a retrenchment in welfare state in principle; however, this is rather a reconfiguration of the welfare state since public institutions only set the scene for social innovation initiatives through, for instance, legal arrangements 
and financial supports, but rarely conduct them on their own. Therefore, this is just a new type and more powerful partnership between public institutions and civil society as well as market actors.

Social innovation practices have become widespread in modern welfare states since it offers a unique complementary expertise. Social needs are more complicated and societal challenges are more confusing than ever. No actor has all the expertise and competency required to overcome a challenge by its own. Therefore, involvement of other actors with their own instruments and resources has become a crucial necessity in modern welfare world. Thanks to social innovation initiatives and their complementary benefits, a special type of self-determination in welfare provision has occurred recently and thereby, a trust is built due to strengthening outreach to more vulnerable groups than before.

Even though civil society organisations mostly take the lead in setting up socially innovative initiatives as expected, this is an open area for other actors in welfare mix as well, particularly for the market actors. In fact, legally and financially involvement of public institutions on both local and central levels increases the possibility of success of social innovation initiatives as well as showing that the state is still the leading actor in the welfare mix.

This clearly suggests that the state has not retreated in welfare provision, but its role has transformed significantly through social innovation. In this sense, the state takes place in social innovation practices through legal and financial facilitator rather than providing direct social protection services as it was during traditional post-war welfare period. In other words, state integrates both formal and informal actors as well as their capabilities and resources through social innovation practices. This seems best practice in welfare and social protection provision in today's world, where new social risks and new societal challenges have emerged and no actor can overcome these by its own.

As the final words, social innovation initiatives rearranged the traditional welfare mix by reallocating the welfare provision responsibility. This has definitely fuelled the purpose of improving overall welfare levels of all citizens in modern welfare states and contributed well to the attempts to get rid of financial crisis of welfare states.

\section{References}

[1] Ascoli, U. and Ranci, C. (2002). Dilemmas of the welfare mix. Boston: Springer US. https://doi.org/10.1007/978-1-4757-4992-2

[2] Bode, I. (2006). Disorganized welfare mixes: voluntary agencies and new governance regimes in Western Europe. Journal of European Social Policy, 16(4), 346-359. https://doi.org/10.1177/0958928706068273

[3] Bonoli, G. (2005). The politics of the new social policies: providing coverage against new social risks in mature welfare states. Policy and Politics, 33(3), 431-449. https://doi.org/10.1332/0305573054325765

[4] Bureau of European Policy Advisors (BEPA) (2011). Empowering people, driving change. Social innovation in the European Union. Brussels: European Commission.

[5] Esping-Andersen, G, (ed) (2002). Why we need a new welfare state. Oxford: Oxford University Press. https://doi.org/10.1093/0199256438.001.0001

[6] Esping-Andersen, G. (1999). Social foundations of postindustrial economies. Oxford: Oxford University Press. https://doi.org/10.1093/0198742002.001.0001

[7] Ewert, B. and Evers, A. (2014). Blueprints for the future of welfare provision? Shared features of service innovations across Europe. Social Policy and Society, 13(3), 423-432. https://doi.org/10.1017/S1474746414000074 
[8] Garland, D. (2014). The Welfare State: A fundamental dimension of modern government. European Journal of Sociology, 55(3), 327-364. https://doi.org/10.1017/S0003975614000162

[9] Gilbert, N. and Gilbert, B. (1989). The enabling state: Modern welfare capitalism in America. New York/Oxford: Oxford University Press.

[10] Gilbert, N. (2002). Transformation of the welfare state: The silent surrender of public responsibility. Oxford: Oxford University Press. https://doi.org/10.1093/0195140745.001.0001

[11] Gough, I. (2000). From welfare to workfare: social integration or forced labour? In European seminar: Policies and instruments to fight poverty in the European Union: the guarantee of a minimum income, 1 - 2 February 2000, Lisbon, Portugal.

[12] Hämäläinen, T. J. and Heiskala, R. (eds) (2007). Social innovations, institutional change and economic performance. Making sense of structural adjustment processes in industrial sectors, regions and societies. Cheltenham: Edward Elgar. https://doi.org/10.4337/9781847206992

[13] https://ec.europa.eu/programmes/horizon2020/en/home, Accessed: 13 July 2021.

[14] Jenson, J.: Modernising paradigms. Social investments via social innovation. 2014 Towards Inclusive Employment and Welfare Systems for a Social Europe Conference, Paper presented at the ImPRovE Working Paper No. 15/19, Berlin.

[15] Jenson, J. (2015). Social innovation: Redesigning the welfare diamond. In Nicholls, A. et al. (Eds.) New frontiers in social innovation research (pp. 89-106). Berlin: Springer. https://doi.org/10.1057/9781137506801_5

[16] Jessop, B. (1991). The welfare state in the transition from Fordism to post-Fordism. In B. Jessop et al. (Eds.), The politics of flexibility: Restructuring state and industry in Britain, Germany and Scandinavia. Brookfield, MA: Edward Elgar.

[17] Jessop, B. (1995). Towards a Schumpeterian workfare regime in Britain? Reflections on regulation, governance and welfare state. Environment and Planning, 27(10), 1613-1626. https://doi.org/10.1068/a271613

[18] Kazepov, Y. (2008). The subsidiarisation of social policies: Actors, Processes and Impacts. Some reflections on the Italian case from a European perspective. European Societies, 10(2), 247-273. https://doi.org/10.1080/14616690701835337

[19] Kazepov, Y. (2010). Rescaling social policies: towards multilevel governance in Europe. Farnham: Ashgate.

[20] Longo, F., Notarnicola, E. and Tasselli, S. (2015). A framework to assess welfare mix and service provision models in health care and social welfare: Case studies of two prominent Italian regions. BMC Health Services Research Open Access

https://doi.org/10.1186/s12913-015-0800-9

[21] Mascini P., M. Soentken and Veen van der R. J. (2011). From welfare to workfare - the implementation of workfare policies. In Van der Veen, R., Yerkes, M. and Achterberg, P. (Eds.), The transformation of solidarity. Amsterdam University Press. https://doi.org/10.1017/9789048515318.009

[22] Morel, N., Palier, B. and Palme, J. (Eds.) (2012). Towards a social investment welfare state? Ideas, policies, challenges. Bristol: The Policy Press. https://doi.org/10.1332/policypress/9781847429247.001.0001

[23] Oosterlynck, S., Novy, A., Kazepov, Y., et al. (2019). Improving poverty reduction: lessons from the social innovation perspective. In Cantillon, B., Goedomé, T. and Hills, J. (Eds.), Improving poverty reduction in Europe. Lessons from the past, scenarios for the future. Oxford: Oxford University Press. https://doi.org/10.1093/oso/9780190849696.003.0009 
[24] Organisation for Economic Cooperation and Development (OECD) (1990). Labour market policies for the 1990s. Paris: OECD.

[25] Powell, M. Barrientos, A. (2011). An audit of the welfare modelling business. Social Policy and Administration, 45(1), 69-84. https://doi.org/10.1111/j.1467-9515.2010.00754.x

[26] Spicker, P. (2008). Social policy: Themes and approaches. Bristol: Policy Press.

[27] Torfing, J. (1999). Towards a Schumpeterian workfare postnational regime: Path-shaping and path-dependency in Danish welfare state reform. Economy and Society, 28(3), 369-402. https://doi.org/10.1080/03085149900000010 